\title{
THE GONADOTROPHIC HORMONE RESPONSE OF ANOESTROUS AND CYCLIC EWES TO SYNTHETIC LUTEINIZING HORMONE-RELEASING HORMONE
}

\author{
A. M. SYMONS, ${ }^{*}$ N. F. GUNNINGHAM AND N. SABA \\ Biochemistry Department, Ministry of Agriculture, Fisheries and Food, \\ Central Veterinary Laboratories, Weybridge, Surrey
}

(Received 1st Fune 1973)

\begin{abstract}
Summary. Anoestrous and cyclic ewes were treated with luteinizing hormone-releasing hormone (LH-RH) by intravenous (i.v.) and subcutaneous (s.c.) injection and by intravenous infusion. Administration of $100 \mu \mathrm{g} \mathrm{LH}-\mathrm{RH}$ by a single i.v. or s.c. injection in anoestrous ewes resulted in elevated plasma levels of LH and FSH. The pattern but not the duration of $\mathrm{LH}$ release from the pituitary was similar to that associated with the onset of oestrus in sheep. The magnitude of the LH and FSH response appeared to be dependent on the amount of LH-RH injected, over the range examined (100 to $500 \mu \mathrm{g}$ ), although the higher doses did not prolong the period of elevated levels. Maximum plasma LH and FSH levels were obtained 1 to $1 \frac{1}{2} \mathrm{hr}$ after i.v. and 2 to $2 \frac{1}{2} \mathrm{hr}$ after s.c. injections. Multiple injections of LH-RH (100 or $250 \mu \mathrm{g}$ ) at 24-hr intervals over 3 days in anoestrous ewes resulted in a progressive decrease in pituitary response although with two injections separated by $3 \mathrm{hr}$ there was a heightened response to the second injection. Intravenous infusion of LH-RH over an $8-\mathrm{hr}$ period $(20 \mu \mathrm{g} / \mathrm{hr})$ did not produce continuously rising levels of LH or FSH. Peak levels were obtained at 2 or $2 \frac{1}{2} \mathrm{hr}$ after starting the infusion and there was then a progressive fall to near preinfusion levels by the end of the infusion. It is suggested that changes in pituitary sensitivity occurred during this period. Cyclic ewes treated with $100 \mu \mathrm{g} \mathrm{LH}-\mathrm{RH}$ at various stages of the oestrous cycle showed similar responses to those of anoestrous ewes and also showed a decreased response to the same dose given $24 \mathrm{hr}$ later. The significance of these results is discussed.
\end{abstract}

\section{INTRODUCTION}

The recent availability of synthetic luteinizing hormone-releasing hormone (LH-RH) has made it possible to study pituitary function in animals at different periods of reproductive activity. Schally \& co-authors (1971) showed that the administration of natural or synthetic LH-RH released LH and FSH from the pituitary gland in various species of animals. In sheep, as with other animals, oestrus coincides with or shortly precedes a surge of $\mathrm{LH}$ release from

* Present address : Department of Biochemistry, University of Surrey, Guildford, Surrey. 
the pituitary, which in turn precedes ovulation by up to $24 \mathrm{hr}$ in sheep penned with rams (Cumming, Brown, Goding, Bryant \& Greenwood, 1972). It was therefore of interest to study the gonadotrophic hormone response to a synthetic LH-RH in anoestrous and cyclic ewes.

\section{MATERIALS AND METHODS}

The synthetic LH-RH (decapeptide) used in all experiments was obtained from Hoechst Pharmaceuticals Ltd and was synthesized by the method of Geiger, König, Wissman, Geisen \& Enzmann (1971).

\section{Radioimmunoassay of ovine FSH and LH}

Levels of LH and FSH in sheep blood plasma were measured using a solidphase radioimmunoassay (RIA) technique. All aspects of the ovine FSH assay have been previously described in detail (Cunningham \& Hebert, 1973). The ovine assay was the same as the FSH assay of Cunningham \& Hebert (1973) but utilized an antiserum raised against bovine LH (NIH-LHB4) at a dilution of 1 in 8000 and ${ }^{125}$ I-labelled bovine LH (NIH-LH-B8). The iodinated bovine LH was purified before each assay, using cellulose adsorption chromatography (Jeffcoate, 1971). The standard ovine LH used for reference in all the assays was NIH-LH-S17. All FSH results were expressed in terms of NIH-FSH-S4.

\section{Radioimmunoassay of progesterone}

A radioimmunoassay utilizing dextran-coated charcoal for the separation of antibody-bound and -free hormone was used (Symons, 1973).

\section{Treatment of experimental animals with $L H-R H$}

Maiden 2-year-old Cheviot ewes were used during their mid-anoestrous period (late April to early July 1972) and during the following breeding season (October 1972 to February 1973). During this period the ewes were run with a vasectomized ram fitted with a marking harness. During the breeding season, the coloured crayon on the harness was changed every 15 days in order to follow the cycle patterns of individual animals. The ewes grazed freely and their diet was supplemented in the morning and afternoon with hay and Ewbol pencils (BOCM Silcock). Intravenous (i.v.) injections of LH-RH were administered through a polythene catheter placed in the jugular vein. Subcutaneous (s.c.) injections were administered mid-way along the back of the animal. Blood samples $(10 \mathrm{ml})$ were collected from jugular vein catheters into heparinized (10 units $/ \mathrm{ml}$ ) bottles or using $10-\mathrm{ml}$ heparinized Vacutainers (Becton, Dickinson UK Ltd). For i.v. infusion studies, the ewes were familiarized with standing in a metabolism cage for 2 days before an experiment. The LH-RH was allowed to infuse through a jugular vein catheter.

\section{RESULTS}

Single intravenous and subcutaneous injections of $L H-R H$ in anoestrous ewes

Text-figure 1 shows the response in individual ewes to an i.v. injection of 
$100 \mu \mathrm{g} \mathrm{LH}-\mathrm{RH}$ in $5 \mathrm{ml} 0.9 \%$ saline (two animals). Text-figure 2 shows the response to 100,250 and $500 \mu \mathrm{g} \mathrm{LH}-\mathrm{RH}$ given s.c. as a $0.01 \%(\mathrm{w} / \mathrm{v})$ solution in $0.9 \%$ saline. Pre-injection levels of $\mathrm{LH}$ were less than $1 \mathrm{ng} / \mathrm{ml}$ plasma in all animals, whereas levels of FSH were between 50 and $75 \mathrm{ng} / \mathrm{ml}$ plasma. Intravenous injections of $100 \mu \mathrm{g} \mathrm{LH}-\mathrm{RH}$ gave peak values of 40 to $70 \mathrm{ng} \mathrm{LH} / \mathrm{ml}$ and 125 to $160 \mathrm{ng} \mathrm{FSH} / \mathrm{ml}$ within 60 to $90 \mathrm{~min}$, although later experiments (see Text-fig. 3) showed the variation in individual animals to be greater. Subcutaneous injections gave peak levels of $\mathrm{LH}$ and FSH some $30 \mathrm{~min}$ later than i.v. injections and, over the range 100 to $500 \mu \mathrm{g}$, there was an indication of a dose-dependent relationship. Elevated levels of LH and FSH were

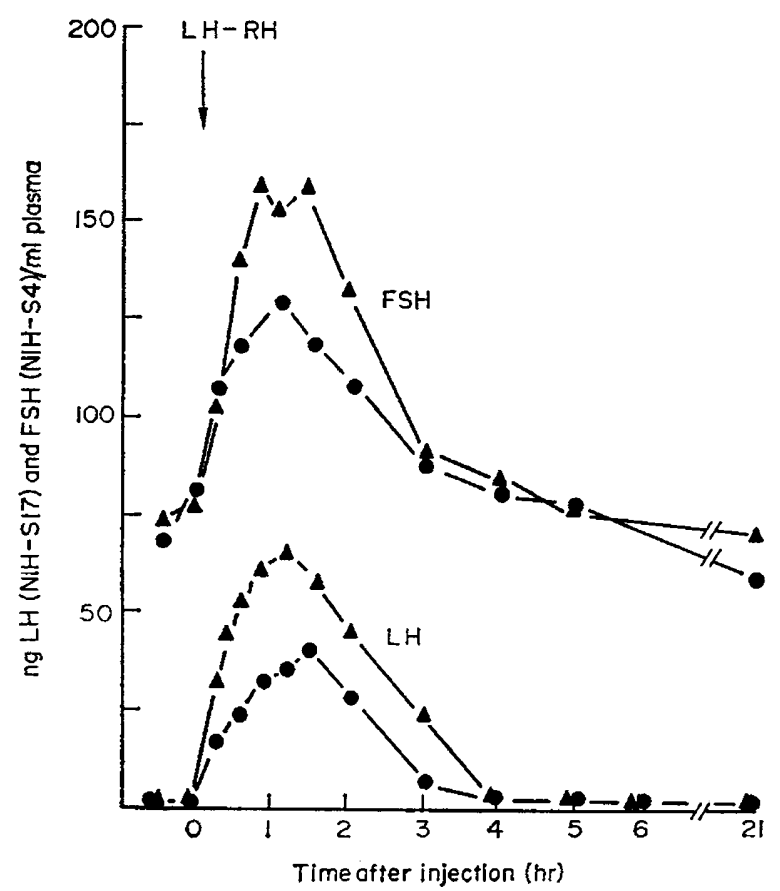

TexT-FIG. 1. The LH and FSH responses in two ewes ( and $\Delta$ ) at mid-anoestrus given an intravenous injection of $100 \mu \mathrm{g} \mathrm{LH}-\mathrm{RH}$.

maintained for a maximum of $5 \mathrm{hr}$. After the 6 -hr sample, the ewes were released into the paddock with the ram but no signs of behavioural oestrus were noted following treatment. The peripheral progesterone concentration in all of the anoestrous ewes was between 0.2 and $0.9 \mathrm{ng} / \mathrm{ml}$ plasma and did not change significantly over the course of the experiment.

Effect in anoestrous ewes of two injections of $L H-R H$

Two ewes were given i.v. injections of $100 \mu \mathrm{g} \mathrm{LH}-\mathrm{RH}$ in $5 \mathrm{ml} 0.9 \%$ saline at $0 \mathrm{hr}$ and $3 \mathrm{hr}$ and the results of this experiment are shown in Text-fig. 3. There was a considerable difference in the peak response of the two animals 
after the first injection (38 and $150 \mathrm{ng} \mathrm{LH} / \mathrm{ml}$ and 111 and $84 \mathrm{ng} \mathrm{FSH} / \mathrm{ml}$ ). The second injection at $3 \mathrm{hr}$ gave much more rapid and heightened responses. Peak levels of 121 and $186 \mathrm{ng} \mathrm{LH} / \mathrm{ml}$ and 146 and $114 \mathrm{ng} \mathrm{FSH} / \mathrm{ml}$ were found 20 to $30 \mathrm{~min}$ after the second injection. The return to basal levels was also more rapid after the second peak, showing a decrease to half-peak levels within 30 min compared to $60 \mathrm{~min}$ with previous single injections.
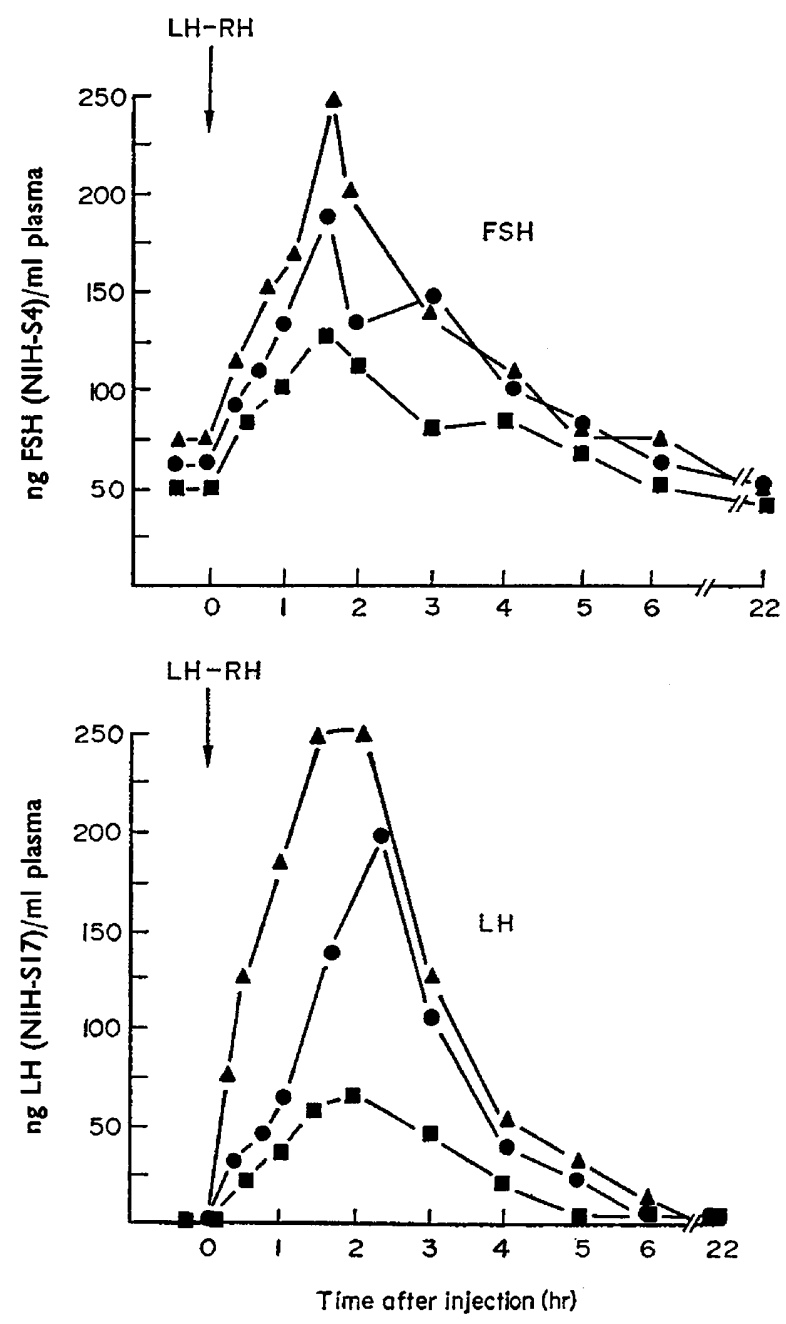

Text-Frg. 2. The LH and FSH responses in three ewes at mid-anoestrus given $100 \mu \mathrm{g}$

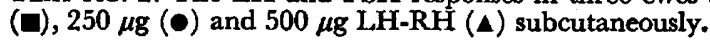

Subcutaneous treatment of anoestrous ewes with $L H-R H$ on 3 consecutive days

Two ewes were injected s.c. with 100 or $250 \mu \mathrm{g}$ LH-RH in 1 or $2.5 \mathrm{ml} 0.9 \%$ saline respectively at 09.00 hours on 3 consecutive days. Blood samples were taken for up to $6 \mathrm{hr}$ each day and the ewe was then released to the ram until 
the following morning. Text-figure 4 shows the results obtained. The responses on Day 1 were typical of those previously obtained but greatly reduced responses were observed on Days 2 and 3 in both cases. The two ewes were treated after 5 weeks with the same dose of LH-RH and it was found that the LH and FSH response was similar to that obtained on Day 1 (see Text-fig. 4). Again, no signs of behavioural oestrus were noted during or following this 3-day experiment and levels of progesterone did not change significantly from their basal level of less than $1 \mathrm{ng} / \mathrm{ml}$ plasma.
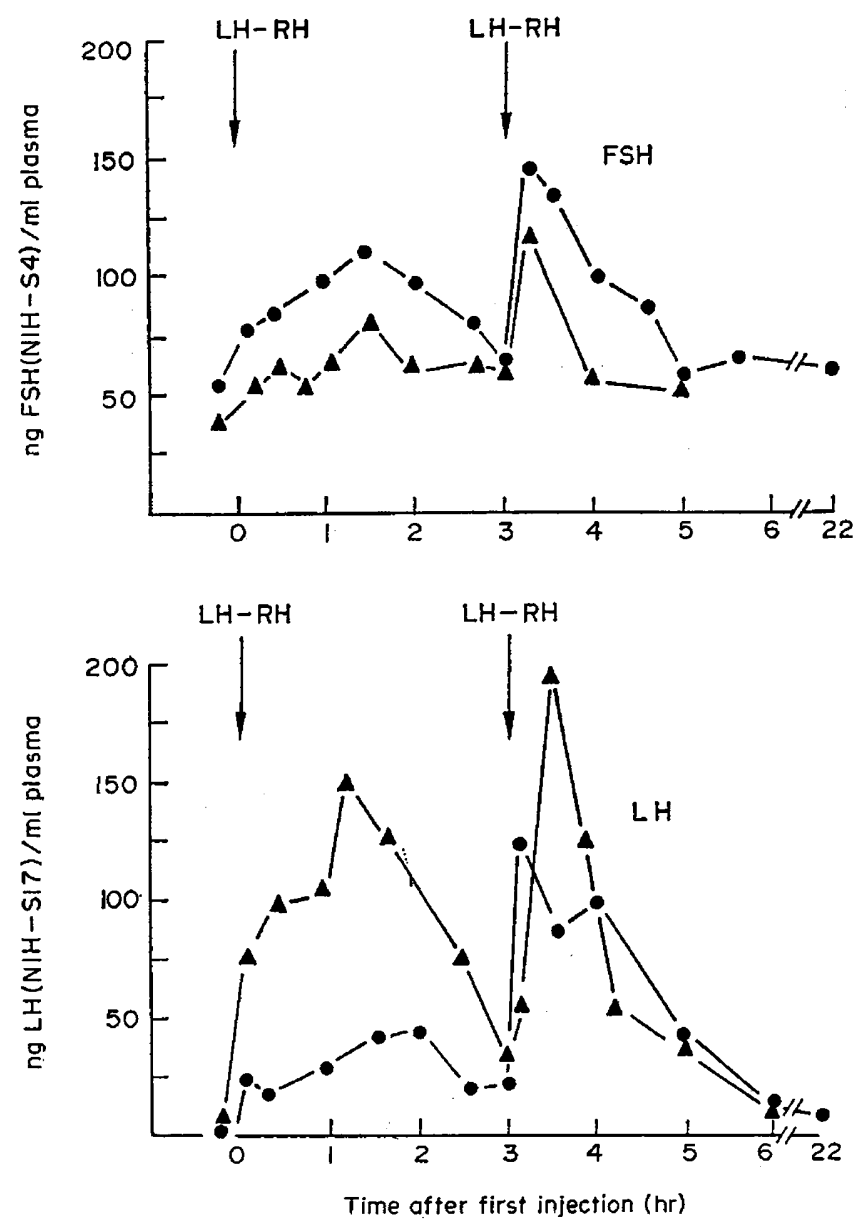

Text-Fig. 3. The LH and FSH responses in two ewes ( 10 and $\Delta$ ) at mid-anoestrus given $100 \mu \mathrm{g}$ LH-RH subcutaneously at zero time and $3 \mathrm{hr}$.

Intravenous infusion of $\mathrm{LH}-\mathrm{RH}$ in anoestrous ewes

Two anoestrous ewes received infusions of LH-RH into the jugular vein over an 8-hr period. Blood samples were taken throughout the infusion period and for $3 \mathrm{hr}$ afterwards. One ewe received a dose of $2 \mu \mathrm{g} \mathrm{LH}-\mathrm{RH} / \mathrm{hr}$ and the other 


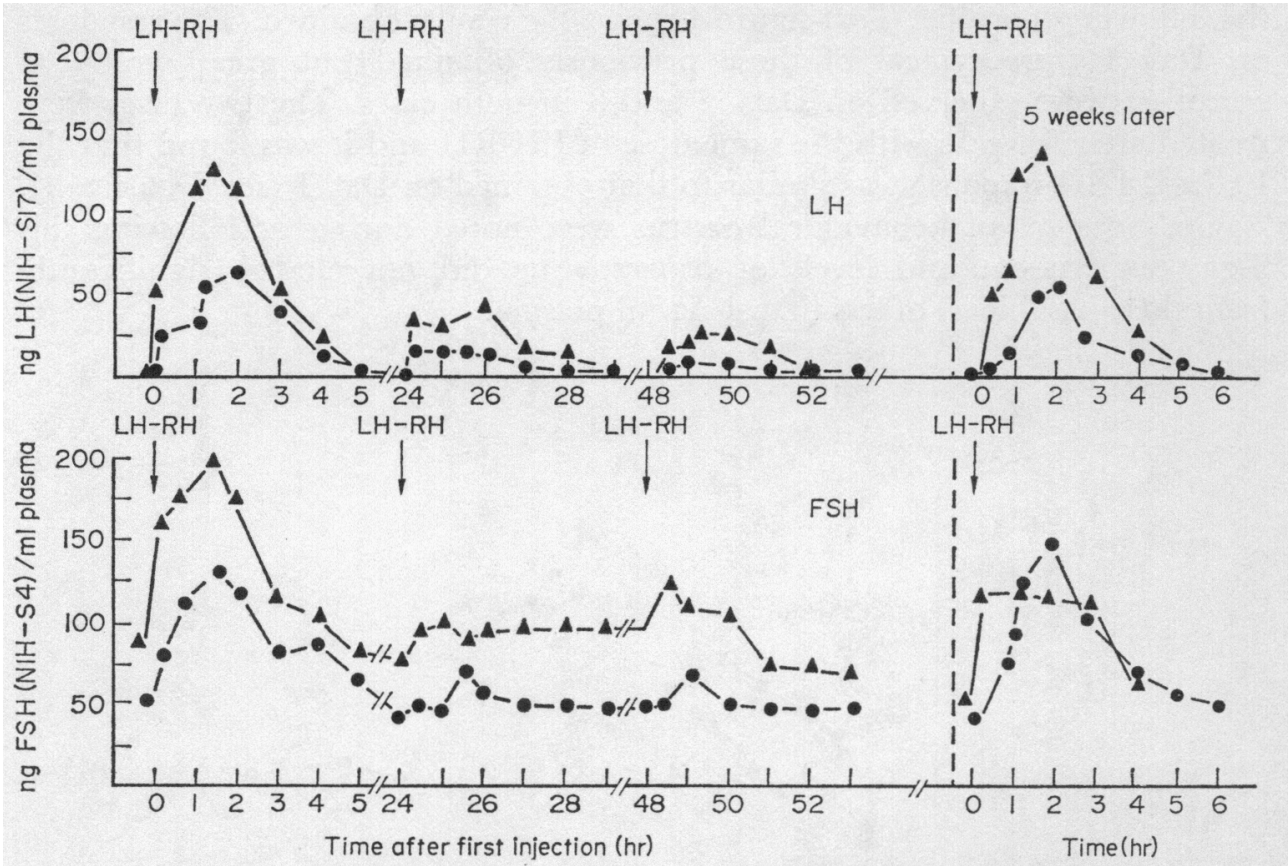

TEXT-FIG. 4. The LH and FSH responses in two ewes at mid-anoestrus given either $100 \mu \mathrm{g}$ (৬) or $250 \mu \mathrm{g} \mathrm{LH}-\mathrm{RH}$ (A) subcutaneously at 09.00 hours on 3 consecutive days and again 5 weeks later.

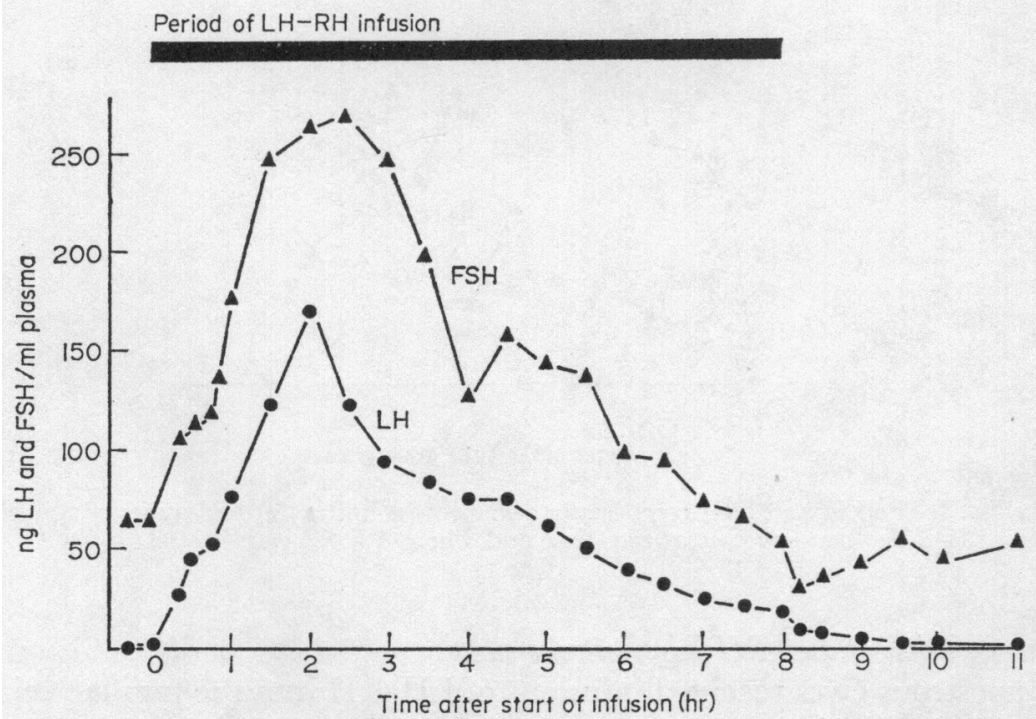

TEXT-Fig. 5. The LH $(\bullet)$ and FSH $(\Delta)$ response in one ewe at mid-anoestrus infused with $\mathrm{LH}-\mathrm{RH}$ at $20 \mu \mathrm{g} / \mathrm{hr}$ for $8 \mathrm{hr}$. 

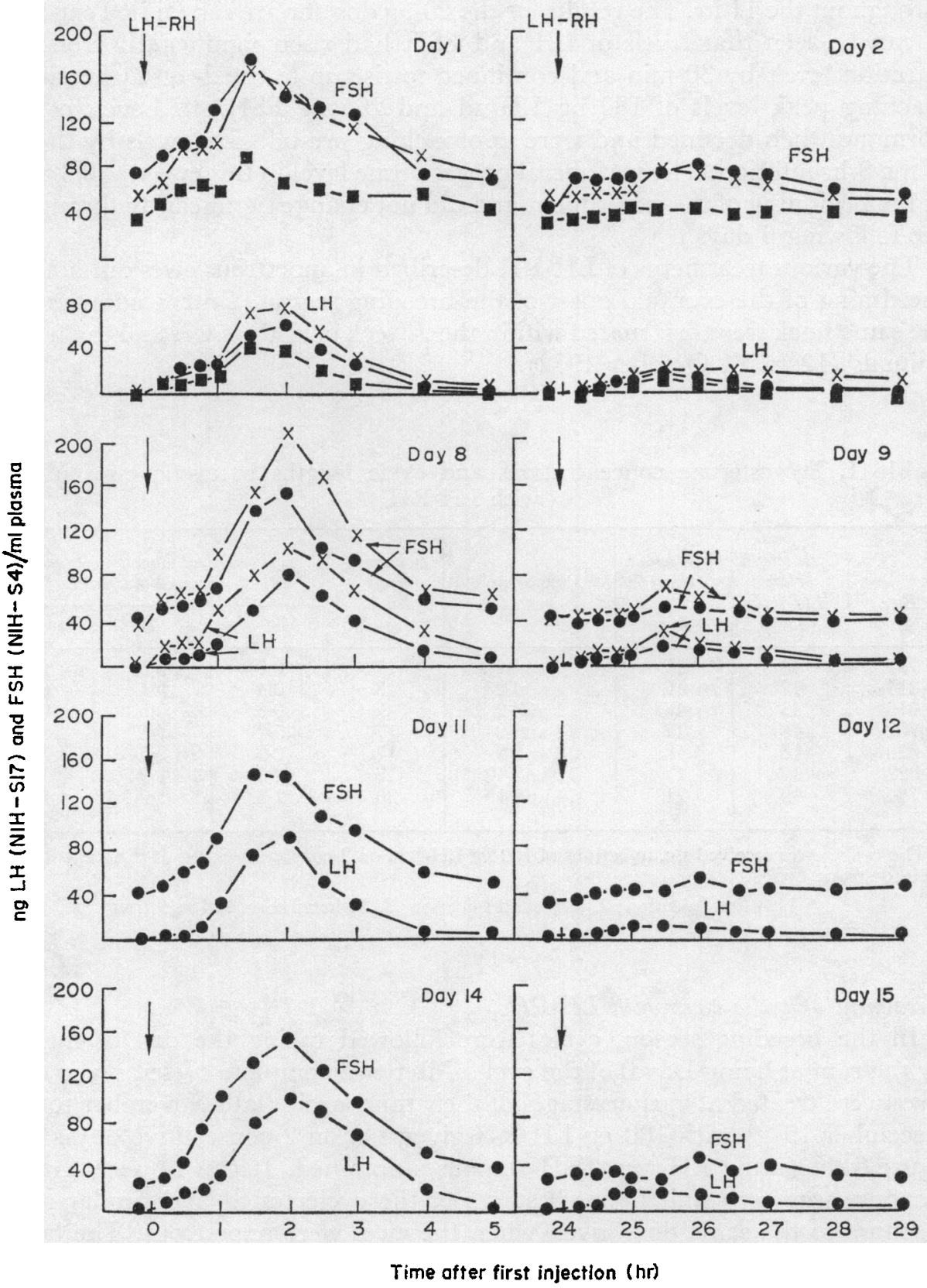

Text-FIG. 6. The LH and FSH responses in seven cyclic ewes injected subcutaneously with $100 \mu \mathrm{g} \mathrm{LH}-\mathrm{RH}$ on 2 consecutive days at different stages of the oestrous cycle. Similar symbols on each of the two consecutive days represent the same animal. 
$20 \mu \mathrm{g} \mathrm{LH}-\mathrm{RH} / \mathrm{hr}$. The LH-RH was infused in $0.9 \%$ saline at a flow rate of $1 \mathrm{ml} / \mathrm{min}$. The lower dose infusion caused no change in levels of LH or FSH throughout the $11 \mathrm{hr}$. The results for the 20- $\mu \mathrm{g}$ dose/hr are shown in Text-fig. 5 . It can be seen that levels of $\mathrm{LH}$ and FSH had risen significantly from preinjection levels by $30 \mathrm{~min}$ and continued to rise up to the 2- or $2 \frac{1}{2}-\mathrm{hr}$ sample, reaching peak levels of $180 \mathrm{ng} \mathrm{LH} / \mathrm{ml}$ and $265 \mathrm{ng} \mathrm{FSH} / \mathrm{ml}$. Levels of both hormones then declined and were approaching pre-infusion levels by the end of the 8-hr infusion. The peripheral progesterone level in this ewe was $0.3 \mathrm{ng} / \mathrm{ml}$ at the beginning of the experiment and did not change significantly throughout the following 6 days.

The various treatments of $\mathrm{LH}-\mathrm{RH}$ described in anoestrous ewes did not alter the timing of the eventual onset of the breeding season. Untreated ewes from the same flock were first mated within the 2-week period, as were all the treated animals (12 to 24 October 1972).

Table 1. Progesterone concentrations and cycle lengths in cyclic ewes injected with LH-RH

\begin{tabular}{|c|c|c|c|c|c|c|c|}
\hline \multirow{2}{*}{ Ewe } & \multirow{2}{*}{$\begin{array}{c}\text { Cycle length } \\
\text { before } \\
L H-R H \\
(\text { days })\end{array}$} & \multirow{2}{*}{$\begin{array}{l}\text { Cycle length } \\
\text { when } \\
\text { treated } \\
\text { (days) }\end{array}$} & \multirow{2}{*}{$\begin{array}{l}\text { Days of cycle } \\
\text { treated }\end{array}$} & \multirow{2}{*}{$\begin{array}{c}\text { Following } \\
\text { cycle } \\
\text { length } \\
\text { (days) }\end{array}$} & \multicolumn{3}{|c|}{$\begin{array}{c}\text { Peripheral progesterone conc. } \\
(\text { ng/ml plasma })^{*}\end{array}$} \\
\hline & & & & & 1 & 2 & 3 \\
\hline $\begin{array}{l}781 \\
814 \\
815 \\
782 \\
820 \\
822 \\
784\end{array}$ & $\begin{array}{l}18 \\
17 \\
15 \\
16 \\
16 \\
17 \\
19\end{array}$ & $\begin{array}{l}17 \\
16 \\
16 \\
17 \\
18 \\
17 \\
21\end{array}$ & $\begin{array}{c}1 \text { and } 2 \\
1 \text { and } 2 \\
1 \text { and } 2 \\
8 \text { and } 9 \\
8 \text { and } 9 \\
11 \text { and } 12 \\
14 \text { and } 15\end{array}$ & $\begin{array}{l}17 \\
18 \\
17 \\
17 \\
17 \\
17 \\
20\end{array}$ & $\begin{array}{l}0 \cdot 7 \\
0 \cdot 4 \\
0 \cdot 3 \\
5 \cdot 2 \\
2 \cdot 9 \\
2 \cdot 5 \\
2 \cdot 5\end{array}$ & $\begin{array}{l}0.5 \\
0.4 \\
0.5 \\
3 \cdot 8 \\
2 \cdot 5 \\
1.9 \\
1.9\end{array}$ & $\begin{array}{l}0 \cdot 5 \\
0 \cdot 3 \\
0 \cdot 7 \\
3 \cdot 9 \\
3 \cdot 3 \\
1 \cdot 2 \\
1 \cdot 7\end{array}$ \\
\hline
\end{tabular}

The cyclic ewes received s.c. injections of $100 \mu \mathrm{g} \mathrm{LH}-\mathrm{RH}$ on 2 consecutive days at different stages of their oestrous cycles.

* 1, at first injection; 2, at second injection; 3, $24 \mathrm{hr}$ after second injection

\section{Treatment of cyclic ewes with $L H-R H$}

In the breeding season, cycles were followed taking the day of marking by the ram as being Day 0 of the cycle. After two complete cycles, seven of the ewes were treated at various stages of their third cycle (late November to early December 1972) with $100 \mu \mathrm{g}$ LH-RH given s.c. on 2 consecutive days. Textfigure 6 shows the LH and FSH responses obtained. It can be seen that the response was very similar at all stages of the cycle tested and similar to the response to the same dose given when the ewes were anoestrous. The lack of response to a second injection of $100 \mu \mathrm{g} \mathrm{LH}-\mathrm{RH} 24 \mathrm{hr}$ after the first was also apparent in every case. Table 1 shows the peripheral progesterone levels in these cyclic ewes at the time of the injections of LH-RH and also the length of their oestrous cycles before, at the time of, and following treatment.

Plasma progesterone levels were low $(<1 \mathrm{ng} / \mathrm{ml})$ in the three ewes treated at the beginning of their cycle (Day 1), high in the two ewes treated at the mid- 
luteal phase (Day 8) showing levels of 5.2 and $2.9 \mathrm{ng} / \mathrm{ml}$, and intermediate $(2.5$ and $1.9 \mathrm{ng} / \mathrm{ml})$ in the two ewes treated on Days 11 and 14 respectively. No significant elevation in progesterone levels was noted during the $48 \mathrm{hr}$ following LH-RH treatment. It can be seen from Table 1 that treatment with LH-RH did not change the cycle length of the animals; all were tupped at the expected time despite the LH surge initiated by LH-RH at various stages of the cycle.

\section{DISCUSSION}

Basal levels of $\mathrm{LH}$ found in the anoestrous ewe $(<\mathrm{Ing} / \mathrm{ml}$ ) are similar to those reported by Scaramuzzi, Caldwell \& Moor (1970). Results show that the pituitary of anoestrous ewes is capable of releasing LH and FSH given the stimulus of LH-RH. The anoestrous period of a ewe does not therefore represent a phase of pituitary gonadotrophic hormone depletion. The results of our studies indicated that stimulation of LH and FSH release by LH-RH was concentration-dependent over the range examined (100 to $500 \mu \mathrm{g})$. The relative increase, compared to basal levels, after LH-RH treatment was very much greater for LH than for FSH in all experiments. The period of elevated LH and FSH levels was not prolonged with the higher doses and did not approach the period of elevated levels (approximately $10 \mathrm{hr}$ ) associated with the preovulatory surge in a normal cyclic ewe (Cumming et al., 1972). Peak levels of peripheral plasma $\mathrm{LH}$ obtained from a $100-\mu \mathrm{g}$ injection of LH-RH were also somewhat lower than the peripheral plasma peak value of $240 \mathrm{ng}$ $\mathrm{LH} / \mathrm{ml}$ reported at oestrus by Bjersing \& co-authors (1972) although considerable variation in this parameter exists from animal to animal.

The experiments on multiple injections of $\mathrm{LH}-\mathrm{RH}$ show some interesting results. Two injections in anoestrous ewes given at zero time and $3 \mathrm{hr}$ gave rise to increased responses with the second injection. Arimura, Debeljuk, Matsuo \& Schally (1972) recently showed that large doses of LH-RH (250 $\mu \mathrm{g})$ in anoestrous ewes gave a biphasic response of $\mathrm{LH}$ release and suggested that the pituitary LH cells may be sensitized during the first phase of stimulation (many of the responses to LH-RH found in the present experiments showed a plateau after $60 \mathrm{~min}$ with a later rise in plasma LH and FSH levels). This sensitization could explain the increased second response found in the double injection experiments. Repeated injections of LH-RH in anoestrous ewes on 3 consecutive days, however, gave diminishing responses on the 2nd and 3rd days.

The progressively decreasing response to daily injections of LH-RH may be due to pituitary depletion or desensitization. It seems unlikely that pituitary depletion was the reason for these observations as greater amounts of LH and FSH could have been released by higher doses of LH-RH. We have also shown (Symons, Cunningham \& Saba, 1973) that $50 \mu$ g oestradiol-17 $\beta$ given s.c. in anoestrous ewes results in a much greater output of LH and FSH from the pituitary (as judged by the area under the response curve) than was found following LH-RH injection. It would seem that pituitary desensitization to LH-RH could explain these results. This insensitivity however, was not 
apparent after $3 \mathrm{hr}$ (see Text-fig. 3). Reeves \& co-authors (1972) also found an increased LH or FSH response in three out of five ewes in late anoestrus injected with $200 \mu \mathrm{g} \mathrm{LH}-\mathrm{RH} 4 \mathrm{hr}$ after an initial injection with the same dose. This suggests that the period of increased pituitary responsiveness to LH-RH is greater than $4 \mathrm{hr}$ but less than $24 \mathrm{hr}$. Reeves, Arimura \& Schally (1971) also showed that the pituitary of the ewe was more sensitive to $3 \mu \mathrm{g} \mathrm{LH}-\mathrm{RH}$ given intra-arterially 4 to $8 \mathrm{hr}$ after the onset of oestrus than at other stages of the cycle. This change in pituitary sensitivity is best illustrated in Text-fig. 5 where continuous infusion of $20 \mu \mathrm{g} \mathrm{LH}-\mathrm{RH} / \mathrm{hr}$ over $8 \mathrm{hr}$ has not resulted in continuously rising levels of LH or FSH. Circulating levels of both hormones declined from peak levels after 2 to $2 \frac{1}{2} \mathrm{hr}$ while LH-RH was still being infused. Up to this 2- to $2 \frac{1}{2}$-hr period, only 40 to $50 \mu \mathrm{g} \mathrm{LH}-\mathrm{RH}$ had actually infused into the animal and peak levels of LH and FSH (180 and $270 \mathrm{ng} / \mathrm{ml}$ plasma respectively) were higher than any levels reached with a $100-\mu \mathrm{g}$ injection of LH-RH in anoestrous or cycling ewes. This experiment came closest to reproducing the pattern of LH secretion at oestrus in the ewe but ovarian activity as reflected by peripheral progesterone concentrations did not alter over the following 6 days. Kerdelhué \& Jutisz (1972) have recently reported that LH-RH can be detected in the systemic blood of cyclic ewes $1 \mathrm{hr}$ before the preovulatory surge of LH and FSH begins and that levels of LH-RH persist for $8 \mathrm{hr}$ after the fall in the level of the gonadotrophins. It therefore seems probable that LH-RH is secreted by the hypothalamus for at least $19 \mathrm{hr}$ during the oestrous phase in the ewe, and that a gonadotrophic hormone regulatory mechanism for endogenously administered LH-RH may be distinct from the natural regulatory mechanism.

The fact that a significant LH and FSH response was obtained on Day 1 of the cycle from $100 \mu \mathrm{g}$ exogenous LH-RH shows that the natural release of LH-RH on the day of oestrus (Day 0) and concomitant release of LH and FSH from the pituitary has not inhibited the response to a similar dose of LH-RH given the following day (Day 1). In both cyclic and anoestrous ewes, the LH and FSH response to exogenous LH-RH $(100 \mu \mathrm{g})$ administered $24 \mathrm{hr}$ after an initial injection of the same dose was greatly reduced in all cases. If endogenous $\mathrm{LH}-\mathrm{RH}$ release is insufficient to cause desensitization of the pituitary to later exogenous LH-RH $(100 \mu \mathrm{g})$, it would seem that the amount of LH-RH released at oestrus is less than the amount of the $100-\mu \mathrm{g}$ injection that actually reaches the pituitary. As injection of $100 \mu \mathrm{g} \mathrm{LH}-\mathrm{RH}$ does not reproduce the LH surge at oestrus, this would again suggest that different gonadotrophic hormone regulatory mechanisms may exist for exogenous and endogenous LH-RH.

Our results also illustrate that the varying levels of endogenous progesterone during the oestrous cycle do not significantly affect the response to $100 \mu \mathrm{g}$ LH-RH. This suggests at first that the ovulatory-blocking action of progesterone is perhaps totally at the hypothalamic level, but Hilliard, Schally \& Sawyer (1971) showed that the ability of LH-RH to overcome progesterone blockage in rabbits was directly related to the dose of LH-RH administered. The 100- $\mu \mathrm{g}$ dose of LH-RH used in the present studies may have been sufficient to overcome any progesterone-blocking action at the pituitary level. 


\section{ACKNOWLEDGMENTS}

We should like to thank Hoechst Pharmaceuticals for the gift of LH-RH and the National Institutes of Health, U.S.A., for pituitary hormone preparations. Mr R. Jackson, Mr J. J. Hattersley and Miss E. M. Dawson are also thanked for skilled technical assistance. One of us (A.M.S.) acknowledges the award of a Treasury Research Fellowship.

\section{REFERENGES}

Arimura, A., Debeljuk, L., Matsuo, H. \& Schally, A. V. (1972) Release of luteinizing hormone by synthetic LH-releasing hormone in the ewe and ram. Proc. Soc. exp. Biol. Med. 139, 851.

Bjersing, L., Hay, M. F., Kann, G., Moor, R. M., Naftolin, F., Scaramuzzi, R. J., Short, R. V. \& YoungLAI, E. V. (1972) Changes in gonadotrophins, ovarian steroids and follicular morphology in sheep at oestrus. F. Endocr. 52, 465.

Gumming, I. A., Brown, J. M., Goding, J. R., Bryant, G. D. \& Greenwood, F. G. (1972) Secretion of prolactin and luteinizing hormone at oestrus in the ewe. F. Endocr. 54, 207.

Cunningham, N. F. \& Hebert, G. N. (1973) A solid-phase radioimmunoassay for ovine follicle-stimulating hormone (FSH). F. Endocr. 58, 239.

Geiger, R., König, W., Wissman, H., Geisen, K. \& Enzmann, F. (1971) Synthesis and characterisation of a decapeptide having LH-RH/FSH-RH activity. Biochem. biophys. Res. Commun. 45, 767.

Hilliard, J., Schally, A. V. \& Sawyer, G. H. (1971) Progesterone blockage of the ovulatory response to intrapituitary infusion of LH-RH in rabbits. Endocrinology, 88, 730 .

Jefrconte, S. L. (1971) Purification of ${ }^{125}$ I-LH and ${ }^{125}$ I-FSH by cellulose adsorption chromatography. In Radioimmunoassay Methods, pp. 30-37. Eds. K. E. Kirkham and W. M. Hunter. Churchill Livingstone, Edinburgh.

Kerdelhut, B. \& Jutisz, M. (1972) Development of a radioimmunoassay of a hypothalamic hormone which stimulates the release of pituitary LH and FSH (LH-RH) using a synthetic decapeptide as antigen. 4th Int. Cong. Endocr., Washington. Excerpta Medica, Amsterdam.

Reeves, J. J., Arimura, A. \& Schally, A. V. (1971) Pituitary responsiveness to purified luteinizing hormone-releasing hormone (LH-RH) at various stages of the estrous cycle in sheep. F. Anim. Sci. 32, 123.

Reeves, J. J., Arimura, A., Schally, A. V., Kragt, G. L., Beck, T. W. \& Gasey, J. M. (1972) Effects of synthetic luteinizing hormone-releasing hormone/follicle stimulating hormone-releasing hormone (LH-RH/FSH-RH) on serum LH, serum FSH and ovulation in anestrous ewes. 7. Anim. Sci. 35, 84.

Scaramuzzi, R. J., Galdwel., B. V. \& Moor, R. M. (1970) Radioimmunoassay of LH and estrogen during the estrous cycle of the ewe. Biol. Reprod. 3,110.

Schaliy, A. V., Arimura, A., Kastin, A. J., Matsuo, H., Baba, Y., Redding, T. W., Nair, R. M. G., DebeljuK, L. \& White, W. F. (1971) Gonadotropin-releasing hormone: one polypeptide regulates secretion of luteinizing and follicle-stimulating hormones. Science, N.Y. 173, 1036.

Symons, A. M. (1973) Levels of oestrogen and progesterone in the cow during the last month of pregnancy. 7. Endocr. 56, 327.

Symons, A. M., Gunningham, N. F. \& Saba, N. (1973) Preliminary observations on the effects of luteinizing hormone-releasing hormone ( $\mathrm{LH}-\mathrm{RH})$ and oestradiol-17 $\beta$ on plasma gonadotrophin levels in the anoestrous ewe. F. Endocr. 58, xii. 